\title{
Identification of Macrophage Colony-Stimulating Factor in Human Milk and Mammary Gland Epithelial Cells
}

\author{
TOSHIRO HARA, KOJI IRIE, SHIGERU SAITO, MOTOHIKO ICHIJO, MUNEO YAMADA, \\ NOBUYA YANAI, AND SUMIO MIYAZAKI \\ Department of Child Neurology, Institute of Neurological Sciences, Tottori University School of Medicine, \\ Yonago [T.H.]; Department of Pathology, Saga Prefectural Hospital, Saga [K.I.]; Department of \\ Obstetrics and Gynecology, Nara Medical University, Nara [S.S., M.I.]; The Biochemical Research \\ Laboratory, Morinaga Milk Industry Co., Ltd., Zama [M.Y., N.Y.]; and Department of Pediatrics, Saga \\ Medical School, Saga, Japan [S.M.]
}

Human milk contains cellular and soluble host-protective components. Macrophages in human milk constitute a major cellular component in contrast to those in the peripheral blood. We have investigated a mechanism of local expansion of macrophages in human milk. First, biologically active macrophage colony-stimulating factor (M-CSF) was identified in human milk. The maximal concentrations of M-CSF in human milk were 10 to 100 -fold higher than those in the serum. The concentrations of $\mathrm{M}-\mathrm{CSF}$ in the milk had no correlation with those in the serum. M-CSF was immunohistochemically detected in the epithelial cells of the ducts and alveoli of the mammary gland. In situ

Human milk contains a variety of cellular and soluble components that may protect infants from infections $(1,2)$. Macrophages constitute a major cellular component $(1,2)$ and can survive under conditions simulating the newborn infant's gastrointestinal tract $(3,4)$. Furthermore, milk macrophages phagocytized infectious pathogens in vitro (5) and were found to release carrying $\operatorname{IgA}$ in association with phagocytosis or surface membrane stimulation $(6,7)$. Therefore, it is suggested that milk macrophages play a role in the host defense.

In the present study, we have investigated a mechanism of local expansion of macrophages in human milk. Because MCSF is a cytokine that induces proliferation and differentiation of macrophages (8), we first studied M-CSF levels in human milk. The maximal M-CSF levels in the colostrum were 10 - to 100 -fold higher than those in the serum. M-CSF is also known to play an essential role in female reproduction $(9-12)$, and the local production of M-CSF in female reproductive organs,

Received March 3, 1994; accepted September 15, 1994.

Correspondence: Toshiro Hara, M.D., Department of Child Ncurology, Institute of Neurological Sciences, Tottori University School of Medicine, 36-1, Nishimachi, Yonago City, 683, Japan.

Supported in part by a grant from the Ministry of Education, Science and Culture, Japan. hybridization study confirmed the local synthesis of M-CSF in the mammary gland epithelial cells. A possible role of female sex steroids was discussed in the regulation of M-CSF production by mammary gland epithelial cells. (Pediatr Res 37: 437-443, 1995)

\author{
Abbreviations \\ M-CSF, macrophage colony-stimulating factor \\ DEAE, diethylaminoethyl \\ TPA, 12-o-tetradecanoyl phorbol-13-acetate
}

placenta and uterus, is regulated by female sex steroids (13, 14). Because the mammary gland is closely involved in reproduction and the development of the milk-secreting apparatus of the mammary gland is also stimulated by female sex steroids (15), we have investigated the local production of M-CSF in the mammary glands by immunohistochemical staining and in situ hybridization. Here, we have shown that the M-CSF protein and mRNA were detected in the mammary gland epithelial cells. A role of female sex steroids in the regulation of M-CSF production by mammary gland epithelial cells was assessed by the study with human breast cancer cell lines.

\section{METHODS}

Milk samples. Human milk samples were obtained from 16 healthy women between 19 and 31 y of age who had delivered mature healthy infants after full-term pregnancy (range: 38-41 wk). Informed consent was obtained from each mother. Milk samples were collected on d 2-6 postpartum and 1 mo after delivery. The specimens were centrifuged at $3000 \mathrm{rpm}$ for 10 min. The lipid layer was removed and the aqueous layer was collected and stored at $-20^{\circ} \mathrm{C}$ until use. The aqueous milk specimens were delipidized with cold ether before use. This step removed a part of inhibitory activity in milk samples. 
Cellular pellets were resuspended in saline, counted, and stained for nonspecific esterase to identify macrophages. Serum samples were collected from the lactating women on $\mathrm{d} 3$ postpartum.

ELISA. M-CSF concentrations in serum, culture supernatants or milk were determined by the ELISA specific for human M-CSF, as described previously (16). First, wells of a flatbottomed, 96-well microtiter plate were incubated with horse anti-human M-CSF Ig in PBS for $24 \mathrm{~h}$ at $4^{\circ} \mathrm{C}$. Each well was washed three times with $0.05 \%$ Tween 20 in PBS using a microtiter washer (Microwasher 120, Flow Laboratories, McLean, VA). Each well was then filled with blocking solution (10\% normal horse serum, $0.25 \% \mathrm{BSA}, 0.02 \% \mathrm{NaN}_{3}$ in PBS) overnight at $4^{\circ} \mathrm{C}$. Each test sample or human M-CSF standard solution was added to a prewashed coated well and incubated for $2 \mathrm{~h}$ at $37^{\circ} \mathrm{C}$. After a wash, rabbit anti-human M-CSF Ig in blocking solution was then added to each well. After incubation for $2 \mathrm{~h}$ at $37^{\circ} \mathrm{C}$, each well was washed and filled with horseradish peroxidase-conjugated goat Ig $\mathrm{G}$ against rabbit Ig in blocking solution without $\mathrm{NaN}_{3}$ for $2 \mathrm{~h}$ at room temperature. After five washes, to each well was added the reaction solution $\left(0.015 \% \mathrm{H}_{2} \mathrm{O}_{2}, 0.8 \mathrm{~g} / \mathrm{L}\right.$ o-phenylenediamine dihydrochloride in $0.1 \mathrm{~mol} / \mathrm{L}$ citrate buffer, $\mathrm{pH} 5.0$ ). After incubation for $30 \mathrm{~min}$ at room temperature in the dark, the reaction was stopped by adding $2 \mathrm{~N} \mathrm{H}_{2} \mathrm{SO}_{4}$ and the color was read on an automatic microtiter plate reader (Twin Reader, Flow Laboratories) using dual beam wavelengths of 492 and $690 \mathrm{~nm}$.

Colony-stimulating activity. Colony-stimulating activity was determined by a monolayer agar culture system containing mouse unfractionated bone marrow cells according to the method described previously (17). One unit was defined as the amount of M-CSF needed to form a colony.

For a neutralization experiment, preincubation was carried out with control rabbit $\operatorname{IgG}$ or $\mathrm{IgG}$ antibody specific for human $\mathrm{M}-\mathrm{CSF}$ for $1 \mathrm{~h}$ at room temperature before colony assay. Rabbit anti-recombinant human M-CSF IgG $(1 \mathrm{~mL})$ neutralizes $120 \times 10^{4}$ units of human M-CSF and does not react with other human colony stimulating factors (16).

Purification and immunoblotting of milk M-CSF. Approximately $100 \mathrm{~mL}$ of colostrum were delipidized with cold ether, concentrated, and desalted. The starting material contained $134.7 \times 10^{4}$ units of M-CSF $(100 \%)$. The sample was first applied to a DEAE Sepharose column preequilibrated with $0.02 \mathrm{~mol} / \mathrm{L}$ sodium phosphate buffer ( $\mathrm{pH} 7.0$ ). After wash with the same buffer, the sample was cluted with the phosphate buffer containing $0.3 \mathrm{~mol} / \mathrm{L} \mathrm{NaCl}(\mathrm{pH} \mathrm{7.0)}$. The eluent was concentrated and desalted. The $0.3 \mathrm{~mol} / \mathrm{L} \mathrm{NaCl}$-eluted fraction from DEAE contained $127.6 \times 10^{4}$ units $(94.7 \%)$ and the DEAE pass-through fraction contained $0.6 \times 10^{4}$ units $(0.4 \%)$. The eluent was further applied to a horse anti-M-CSF Igcoupled immunoaffinity column, as described previously (18). After washing with PBS containing $0.3 \mathrm{~mol} / \mathrm{L} \mathrm{NaCl}, \mathrm{M}-\mathrm{CSF}$ was cluted with $3.5 \mathrm{~mol} / \mathrm{L}$ potassium thiocyanate in $0.1 \mathrm{~mol} / \mathrm{L}$ phosphate buffer. The eluent was concentrated and subjected to SDS-PAGE. After electrophoresis, the proteins on the gel were transferred to a nylon membrane in blotting buffer with an clectroblotting apparatus (Funa-Blotting Set, Funakoshi, Tokyo, Japan). The membrane was blocked with $3 \%$ BSA in PBS and probed with rabbit anti-recombinant human M-CSF antibody for $12 \mathrm{~h}$. After washing the membrane with PBS containing $0.05 \%$ Tween 20 , the membrane was treated with peroxidase-conjugated goat $\operatorname{lgG}$ against rabbit $\operatorname{IgG}$, followed by $\mathrm{H}_{2} \mathrm{O}_{2}$ and $o$-phenylenediamine dihydrochloride (18).

Immunohistochemical staining of M-CSF. Mammary gland specimens were obtained from patients with breast tumors (fibroadenoma, fibrocystic disease, cancer) including four lactating women aged 25 to 34 y ( 3 wk to 6 mo after delivery), six nonlactating premenoposal women aged 20 to $40 \mathrm{y}$, and three postmenoposal women aged 68 to $72 \mathrm{y}$. No mammary gland specimens were available from women in the last trimester of pregnancy or immediately after delivery. Immunohistochemical staining of M-CSF was performed with rabbit anti-recombinant human M-CSF IgG or control rabbit IgG and Universal DACO LSAB Kit K680 (Dako Japan Co. Ltd., Kyoto, Japan). The specimen was first incubated for 5 min with $3 \%$ hydrogen peroxide, followed by a 5 -min incubation with blocking serum. The specimen was then incubated with rabbit anti-recombinant human M-CSF IgG or control rabbit IgG for 10 min. Each incubation was followed by a wash with PBS. The specimen was incubated with biotinylated second antibody for $10 \mathrm{~min}$ and with peroxidase-labeled streptavidin for $10 \mathrm{~min}$. Staining was completed after a 10 -min incubation with $3 \%$ 3-amino-9-ethylcarbazole.

In situ hybridization. Human 1.8-kb M-CSF cDNA (kindly provided by the Genetics Institute, Boston, MA) was inserted into Bluescript. Using a digoxigenin RNA labeling kit (Boehringer Mannheim, Mannheim, Germany), sense RNA and antisense RNA probes were prepared from $1 \mu \mathrm{g}$ of temperate DNA fragment. Frozen sections ( $4 \mu \mathrm{m}$ in thickness) were mounted on gelatin-coated glass slides. After air drying, the sections were immersed in a fixative $(4 \%$ paraformaldehyde in PBS, $\mathrm{pH}$ 7.4) for $5 \mathrm{~min}$ and were subsequently washed in PBS. The slides were then incubated for $10 \mathrm{~min}$ in a solution containing $50 \mathrm{mM}$ Tris- $\mathrm{HCl}(\mathrm{pH} 7.4), 5 \mathrm{mM}$ EDTA, and $10 \mu \mathrm{g} / \mathrm{mL}$ of proteinase $\mathrm{K}$ (Boehringer Mannheim) at $37^{\circ} \mathrm{C}$. These slides were incubated for $10 \mathrm{~min}$ in $0.25 \%$ acetic anhydride in $0.1 \mathrm{M}$ triethanolamine buffer ( $\mathrm{pH} \mathrm{8.0)}$ at room temperature. After washing in PBS and dehydration in ethanol, the slides were subjected to an overnight hybridization at $43^{\circ} \mathrm{C}$ in a buffer that contained $3 \mu \mathrm{g} / \mathrm{mL}$ of digoxigenin-labeled RNA, $50 \%$ formamide, $0.3 \mathrm{M} \mathrm{NaCl}, 20 \mathrm{mM}$ Tris- $\mathrm{HCl}$ ( $\mathrm{pH} 7.4$ ), 5 mM EDTA, $10 \mathrm{mM} \mathrm{NaH} \mathrm{PO}_{4}(\mathrm{pH} 8.0), 10 \%$ dextran sulfate, $1 \times$ Denhardt's solution, $10 \mathrm{mM}$ DTT, $250 \mu \mathrm{g} / \mathrm{mL}$ of salmon sperm DNA, and yeast RNA. After hybridization, the slides were washed in $2 \times \mathrm{SSC}(1 \times \mathrm{SSC}: 0.15 \mathrm{M} \mathrm{NaCl}, 0.015 \mathrm{M}$ trisodium citrate, $\mathrm{pH} 7.0$ ) for $30 \mathrm{~min}$ at $60^{\circ} \mathrm{C}$, followed by a 30 -min incubation in $2 \times \mathrm{SSC}, 50 \%$ formamide solution at $60^{\circ} \mathrm{C}$ and a subsequent 5 -min incubation in $0.1 \times \mathrm{SSC}$ solution at $40^{\circ} \mathrm{C}$. The color of the probe was then developed using a Dig detection kit (Boehringer Mannheim) (19).

In vitro stimulation of breast cancer cells with hormones. Breast cancer cell lines, MCF-7 and ZR-75-1, were kindly provided by Dr. T. Kubota, Department of Surgery, Keio University, Tokyo, Japan. MRK-nu-1 and YMB-1 were provided by Japanese Cancer Research Resources Bank-Cell, Tokyo, Japan. All four cell lines carry estrogen receptors 
(20-23). 17 $\beta$-Estradiol and TPA were purchased from Sigma Chemical Co. (St. Louis, MO).

Cells were cultured in Eagle's minimum essential medium (Nissui Co. Ltd., Yuhki, Japan) supplemented with 10\% FCS (Gibco Laboratories, Grand Island, NY), L-glutamine (0.292 $\mathrm{g} / \mathrm{L})$, and kanamicin $(0.06 \mathrm{~g} / \mathrm{L})$. At $60-80 \%$ confluency, cells were cultured in the presence of various concentrations of estradiol or TPA. After $24 \mathrm{~h}$, the supernatants were collected and stored at $-80^{\circ} \mathrm{C}$ for cytokine assays.

Statistical analysis. Assessment of correlations between variables was made by Pearson correlation analysis. The significance of the relationships was tested by the $t$ test.

\section{RESULTS}

Identification of M-CSF in human milk. We examined whether the ELISA system established for the quantitation of serum M-CSF (18) was applicable to the determination of milk M-CSF concentrations. First, the recovery of exogenous MCSF in milk was studied. Various amounts (2000-10000 $\mathrm{U} / \mathrm{mL}$ ) of exogenous M-CSF were added to defatted human milk specimens, and M-CSF concentrations were measured by the ELISA. The ratios of the measured and caliculated concentrations were $101.4 \pm 7.5 \%$ (mean $\pm \mathrm{SD}$ ), which means that most of the added M-CSF was recovered by the ELISA without inhibition. At 20 - to 100 -fold dilutions, calculated M-CSF concentrations were almost constant as long as measured M-CSF concentrations were within the quantitative linear region $(20-400 \mathrm{U} / \mathrm{mL})$ of the standard curve (18). The within-run imprecision expressed as a coefficient of variation was below $10 \%$.

Milk M-CSF concentrations were serially measured on $\mathrm{d}$ 2-6 postpartum. Maximal M-CSF concentrations were observed on $\mathrm{d} 2$ postpartum in most cases with a great variation between 52470 and $3740 \mathrm{U} / \mathrm{mL}$, as shown in Figure 1. Then, milk M-CSF concentrations declined rapidly to less than $10000 \mathrm{U} / \mathrm{mL}$. One month after delivery, milk M-CSF concentrations were $1150 \pm 120 \mathrm{U} / \mathrm{mL}$ (mean $\pm \mathrm{SD}$ ). At this time, seven samples were collected because of a little individual variation.

Molecular form of milk M-CSF. Milk M-CSF was purified by a DEAE Sepharose and anti-M-CSF antibody-coupled immunoaffinity column, as described in Methods. Purified MCSF was subjected to SDS-PAGE and Western blotting analysis. As shown in Figure 2, the molecular mass of milk M-CSF was approximately $80 \mathrm{kD}$ under nonreduced conditions and 40 $\mathrm{kD}$ under reduced conditions. Thus, the molecular structure of milk M-CSF was an 80-kD disulfide-liked homodimer similar to that of serum or urine M-CSF.

Biologic activity of milk M-CSF. Determination of colonystimulating activity by a monolayer agar culture showed a significant positive correlation between colony-stimulating activity and ELISA units in milk with a correlation coefficient of $0.977(p<0.01)$, as shown in Table 1.

To exclude the possibility that the colony-stimulating activity observed was due to other contaminants in the milk, neutralization experiments with anti-M-CSF antibody were performed. The colony-stimulating activity was strongly inhib-

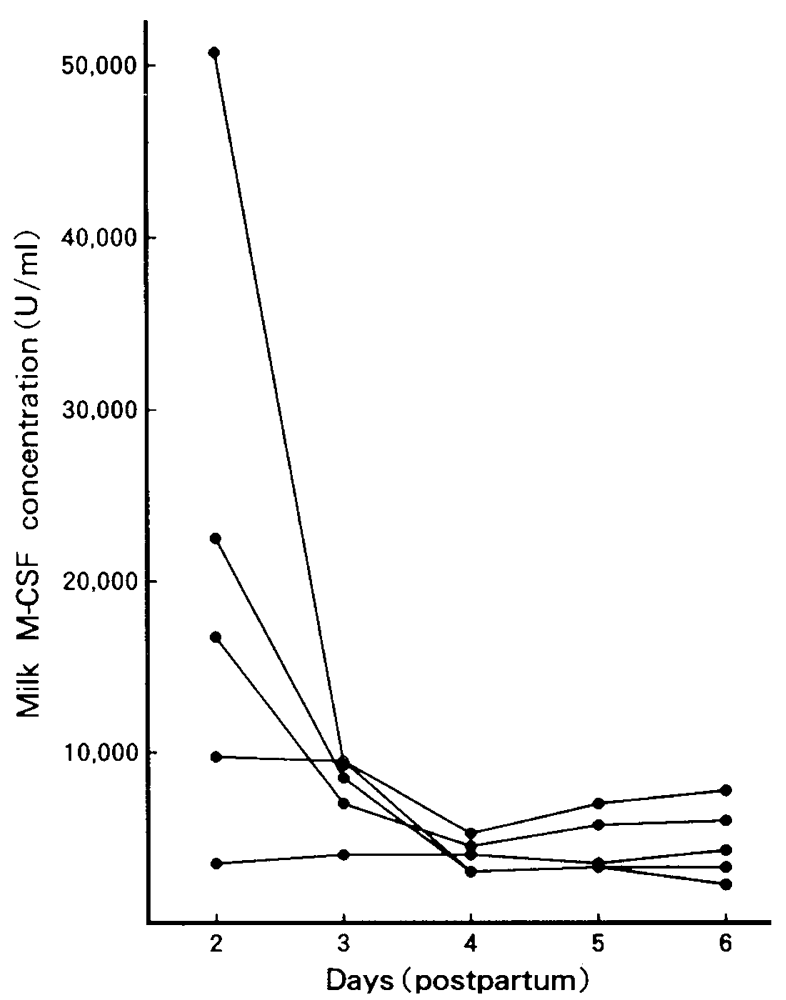

Figure 1. Serial determination of milk M-CSF concentrations.

ited by preincubation with anti-M-CSF $\operatorname{IgG}$ (mean percent inhibition \pm SD: $84.3 \pm 5.9 \%, n=4$ ) but not with control $\operatorname{IgG}$ $(2.9 \pm 2.5 \%, n=4)$.

Simultaneous comparison of milk and serum M-CSF concentrations. To determine whether milk M-CSF was derived from serum M-CSF, we examined milk and serum M-CSF concentrations simultaneously on $\mathrm{d} 3$ postpartum. As shown in Figure 3, despite high milk M-CSF concentrations, serum M-CSF concentrations were consistently less than $1000 \mathrm{U} / \mathrm{mL}$ $(p>0.1)$. Thus, it is less likely that milk M-CSF was derived from serum.

Immunohistochemical localization of M-CSF in mammary gland specimens. M-CSF was immunohistochemically detected in the epithelial cells of the alveoli of the mammary gland obtained from lactating women (Fig. $4 A$ ) and in the epithelial cells of the ducts in nonlactating premenoposal (Fig. $4 C)$ and postmenoposal women.

Detection of M-CSF mRNA in mammary gland tissue sections by in situ hybridization. M-CSF mRNA was mainly expressed in the epithelial cells of the ducts of the mammary gland (Fig. 5). No significant mRNA was detected in the mammary gland tissue sections when control sense probe was used.

Stimulation of human breast cancer cells with female sex steroids. To investigate whether female sex stcroids have effects on the secretion of M-CSF by the mammary gland epithelial cells, cloned cell lines of human breast cancer were used. Four cell lines derived from the mammary gland were cultured in the presence of various concentrations of $17 \beta$ estradiol or TPA that induce differentiation of tumor cells (24). Estradiol and TPA did not affect cell viability at all. As shown in Figure 6, MRK-nu-1 cells constitutively produced M-CSF, 


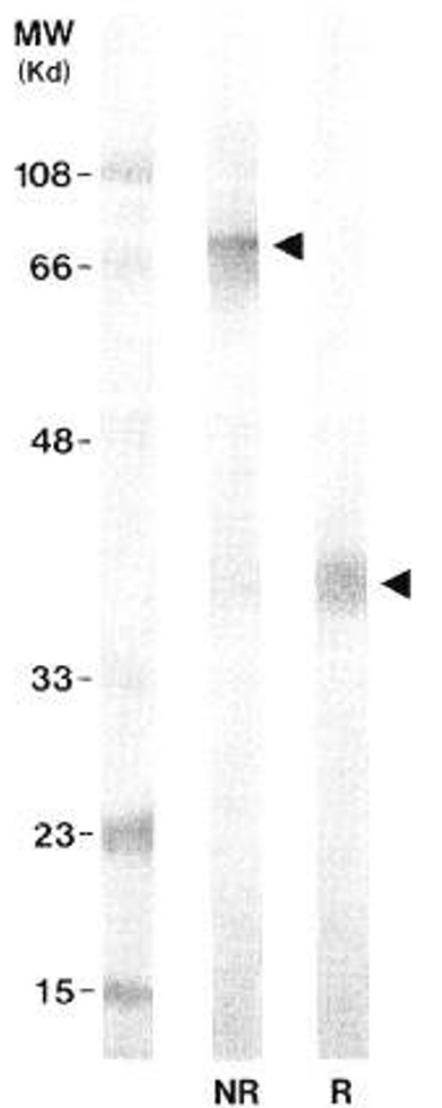

Figure 2. Molecular structure of milk M-CSF. Arrowheads indicate the molecular weights $(M W)$ of milk M-CSF under nonreduced $(N R)$ and reduced $(R)$ conditions.

Table 1. Correlation between biologic activity and ELISA data of milk $M$-CSF

\begin{tabular}{ccc}
\hline Milk sample & $\begin{array}{c}\text { Biologic activity } \\
\text { (units) }\end{array}$ & $\begin{array}{c}\text { ELISA data } \\
\text { (units) }\end{array}$ \\
\hline 1 & 2300 & 3000 \\
2 & 5700 & 5000 \\
3 & 1000 & 2000 \\
4 & 4500 & 5000 \\
5 & 400 & 2000 \\
\hline
\end{tabular}

Colony-stimulating activity was determined by a monolayer agar culture system containing mouse unfractionated bone marrow cells. One unit was defincd as the amount of M-CSF needed to form a colony. A significant correlation was observed between biologic activity and ELISA data $(p<0.01)$.

and its production was significantly enhanced by TPA $(p<$ 0.01 ) but not by estrogen. MCF-7 produced a small amount of $\mathrm{M}$-CSF in response to $100 \mathrm{nmol} / \mathrm{L}$ of estradiol in the presence of TPA. ZR-75-1 produced M-CSF in response to $100 \mathrm{nmol} / \mathrm{L}$ of estradiol in the presence or absence of TPA. YMB- 1 cells produced no detectable M-CSF to any stimulation.

\section{DISCUSSION}

Human milk contains cellular and soluble components with antiinfective properties $(1,2)$ and protects infants from infections (25). In the present study, we have investigated how macrophages are expanded as a major cellular component in human milk.

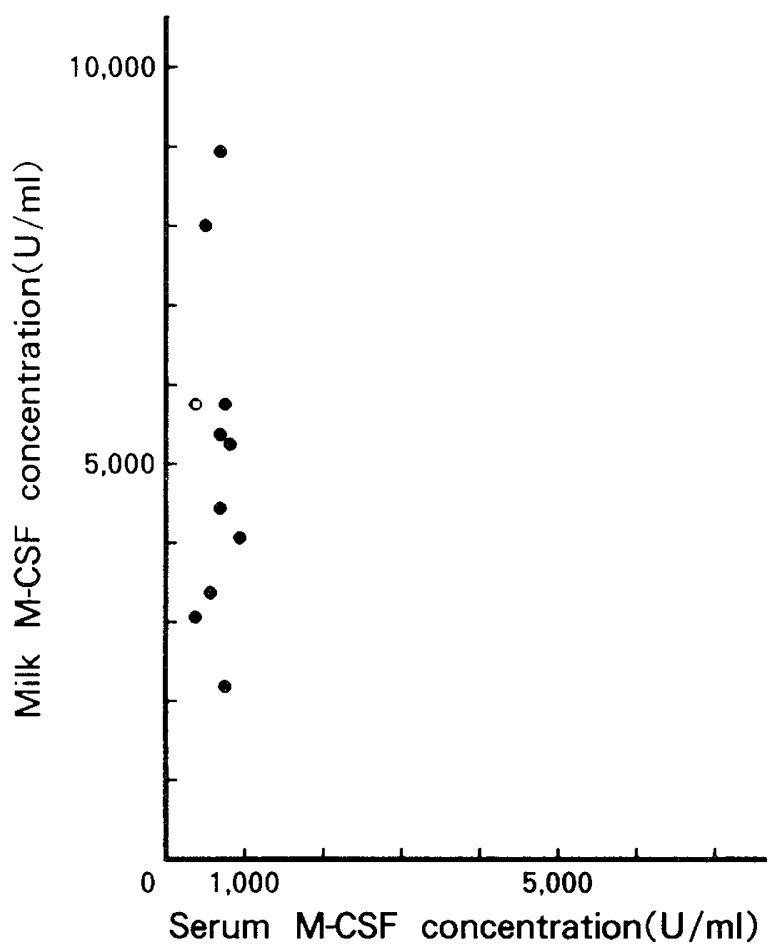

Figure 3. Simultaneous determination of milk and serum M-CSF concentrations.

We have found that human milk contained a large amount of biologically active M-CSF that could induce proliferation and differentiation of macrophages (8). Because concentrations of serum M-CSF were neither elevated nor correlated with those of milk M-CSF, it was suggested that the concentrating mechanism of M-CSF from the blood would not be a major one for high M-CSF levels of milk. With respect to cytokines, local production is common but no concentrating mechanism from the blood is known for local enrichment. Therefore, we assumed that milk M-CSF was produced locally in the mammary gland. It is conceivable that milk macrophages produced MCSF in human milk because milk macrophages secrete most cytokines as peripheral blood monocytes do (26). However, production of M-CSF by milk macrophages themselves cannot explain an initial event of macrophage enrichment in human milk. Recent studies have shown that M-CSF is produced locally in the human placenta and uterus $(11,12)$. The present study has demonstrated that M-CSF was produced locally in the epithelial cells of the mammary gland. Because there was no great difference among the M-CSF-staining intensities of the mammary gland epithelial cells obtained during lactating, nonlactating premenoposal, and postmenoposal periods, it was suggested that mammary gland epithelial cells synthesize a certain amount of M-CSF at the three periods. However, because there is a great difference among the total cell numbers of the M-CSF-producing epithelial cells of the mammary gland at the three periods, female sex steroids might partly regulate M-CSF synthesis by controling the total cell number of M-CSF-producing epithelial cells of the mammary gland by inducing the ductal and lobuloalveolar development.

In addition, studies with cloned cell lines of mammary gland epithelial cells revealed that two cell lines, MCF-7 and ZR- 


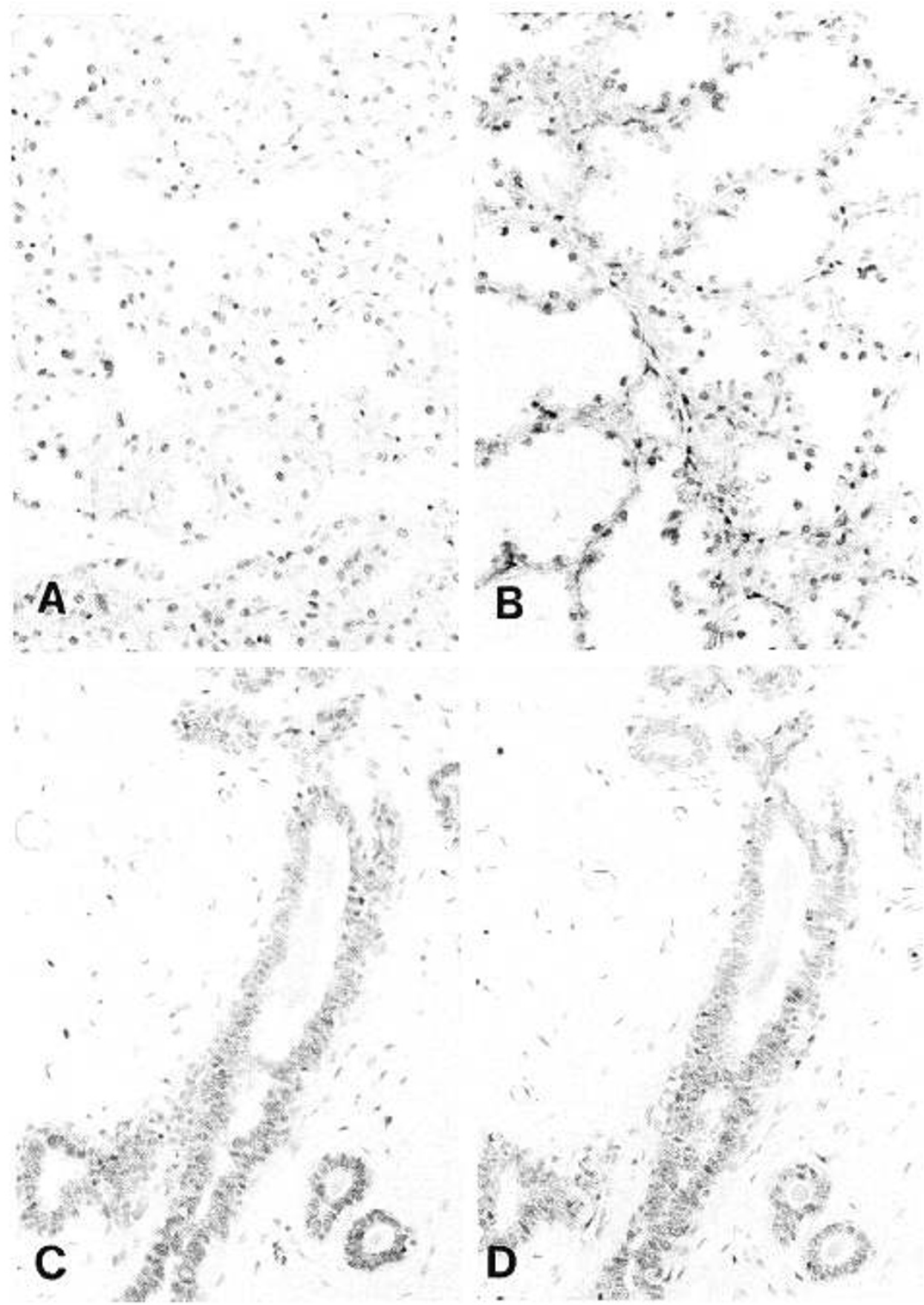

Figure 4. Immunohistochemical staining of the human mammary gland specimens. Epithelial cells of the alveoli of the mammary gland at the lactating period were stained with anti-M-CSF antibody $(A)$ and control antibody $(B)$. Epithelial cells of the ducts of the mammary gland at the nonlactating premenoposal period were stained with anti-M-CSF antibody $(C)$ and control antibody $(D)$

$75-1$, produced $\mathrm{M}$-CSF in response to $100 \mathrm{nmol} / \mathrm{L}$ of estrogen in the presence of TPA and to $100 \mathrm{nmol} / \mathrm{L}$ of estrogen with or without TPA, respectively. Although slight enhancement of cell multiplication was observed during the $24 \mathrm{~h}$ in the presence of $1-100 \mathrm{nmol} / \mathrm{L}$ of estradiol, M-CSF production was not simply attributable to cell multiplication because no M-CSF was produced at the optimal concentrations $(1-10 \mathrm{nmol} / \mathrm{L})$ for cell growth $(27,28)$. Although further confirmation using normal mammary gland epithelial cells is required before conclusions are made, it is possible that female sex steroids play a regulatory role in the production of M-CSF by the mammary gland epithelial cells at a single-cell level.
Thus, female sex steroids may play a role in the production of a major host-protective cellular component, macrophages, partly by stimulating M-CSF secretion by the mammary gland epithelial cells at a single-cell level and partly by controlling the total cell number of the epithelial cells of the mammary gland. Once milk macrophages are expanded by M-CSF derived from the epithelial cells of the mammary gland, it is likely that milk macrophages secrete M-CSF in an autocrine fashion. It remains to be determined whether other cytokines such as granulocyte macrophage-colony-stimulating factor, IL-3, and IL-4 are also involved in the production of milk macrophages. 

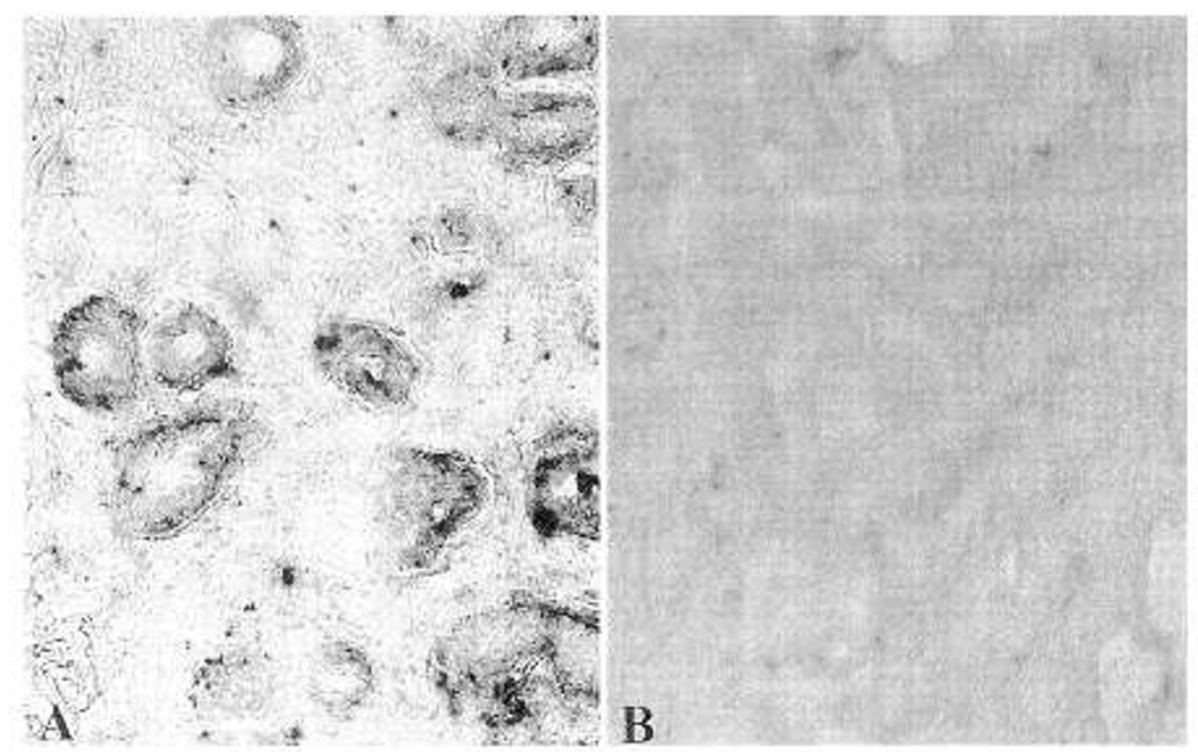

Figure 5. Localization of M-CSF mRNA in the mammary gland tissue sections. Antisense RNA probe for M-CSF $(A)$ and control sense RNA probe for M-CSF $(B)$. M-CSF mRNA was detected in the epithelial cells of the mammary gland.

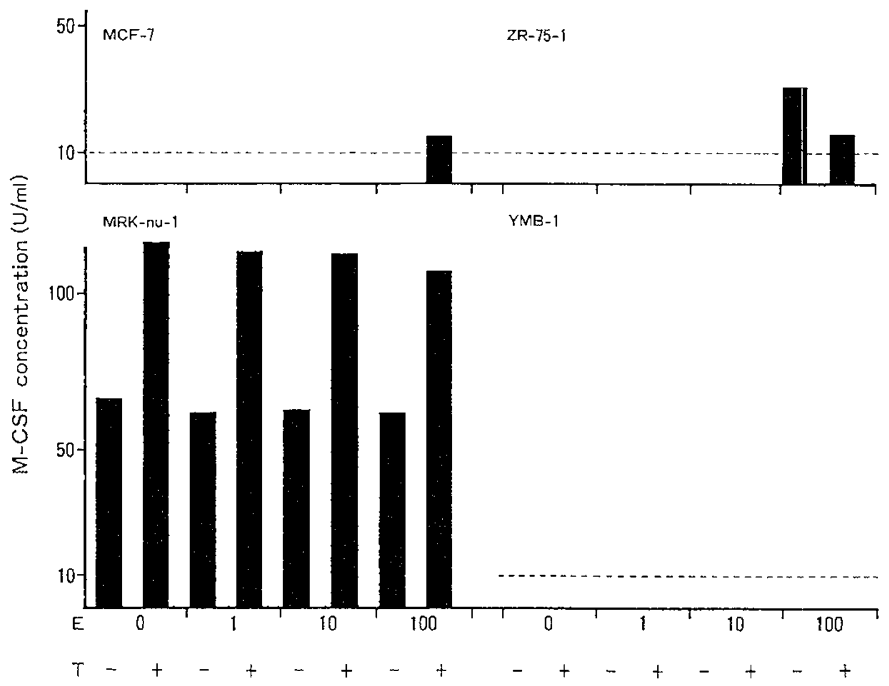

Figure 6. Effect of estrogen and TPA on the secretion of M-CSF by human breast cancer cells. Human breast cancer cell lincs, MCF-7, ZR-75-1, MRKnu-1, and YMB-1 were cultured in the presence of $0,1,10$, or $100 \mathrm{nmol} / \mathrm{L}$ of $17 \beta$-estradiol $(E)$ or TPA $(T)(-: 0 \mu \mathrm{g} / \mathrm{L} ;+: 100 \mu \mathrm{g} / \mathrm{L})$ for $24 \mathrm{~h}$. The culture supernatants were collected and assayed for M-CSF.

IL-1, IL-6, and tumor necrosis factor- $\alpha$ were detected in human milk (29-33). Because these cytokines were also produced in the female reproductive organs (34-36) and induced by estrogen and progesterone (36), there is a possibility that these cytokines are also derived from the mammary gland under the regulation of hormones.

Acknowledgments. The authors thank the obstetrics ward staff, Saga Prefectural Hospital, for providing milk and blood samples, and Professor Kenzo Takeshita, Tottori University, for reviewing the manuscript.

\section{REFERENCES}

1. Hanson LA, Brandtzacg P 1989 The mucosal defense system. In: Stiem ER (ed) Immunologic Disorders in Infants and Children. WB Saunders, Philadelphia, pp $116-155$
2. Strober W, James SP 1991 The mucosal immune system. In: Stites DP, Terr SP (eds) Basic and Clinica! Immunology. Appleton \& Lange, East Norwalk, CT, pp 175-186

3. Paxson CL, Cress CC 1979 Survival of human milk leukocytes. J Pediatr 94:61-64

4. Jain L, Vidyasagar D, Xanthou M, Ghai V, Shimada S, Blend M 1989 In vivo distribution of human milk leukocytes after injection by newborn baboons. Arch Dis Child 64:930-933

5. Ho PC, Lawton JWM 1978 Human colostrum cells: phagocytosis and killing of $E$. coli and C. albicans. J Pediatr 93:910-915

6. Weaver EA, Tsuda H, Goldblum RM, Goldman AS, Davis CP 1982 Relationship between phagocytosis and immunoglobulin A release from human colostral macrophages. Infect Immun 38:1073-1077

7. Weaver EA, Rudloff HE, Goldblum RM, Davis CP, Goldman AS 1984 Secretion of immunoglobulin $\mathrm{A}$ by human milk leukocytes initiated by surface membrane stimuli. J Immunol 132:684-689

8. Stanley ER, Guilbert LJ, Tushinksi RJ, Bartelmez SH 1983 CSF-1: a mononuclear phagocytc lincage-specific hemopoictic growth factor. J Cell Biochem 21:151-159

9. Bartocci A, Pollard JW, Stanley ER 1986 Regulation of colony stimulating factor-1 during pregnancy. J Exp Med 164:956-961

10. Arceci RJ, Shanahan F, Stanley ER, Pollard JW 1989 The temporal expression and location of colony stimulating factor-1 (CSF-1) and its receptor in the female reproductive tract are consistent with CSF-1 regulated placental development. Proc Natl Acad Sci USA 86:8818-8822

11. Kauma SW, Aukerman SL, Eicrman D, Turner T 1991 Colony-stimulating factor-1 and $\mathrm{c}$-fms expression in human endometrial tissues and placenta during the menstrual cycle and early pregnancy. $\mathrm{J}$ Clin Endcrin Mctabol 73:746-751

12. Daiter E, Pampfer S, Yeung YG, Barad D, Stanley ER, Pollard JW 1992 Expression of colony-stimulating factor-1 in the human utcrus and placenta. J Clin Enderinol Metabol 74:850 - 858

13. Pollard JW, Bartocci A, Arceci R, Orlofsky A, Ladner MB, Stanley ER 1987 Apparent role of the macrophage growth factor, CSF-1, in placental development. Nature 330:484-486

14. Azuma C, Saji F, Kimura T, Tokugawa Y, Takcmura M, Samcjima $Y$, Tanizawa $O$ 1992 Steroid hormones induce macrophage-colony stimulating factor (MCSF) and MCSF receptor mRNAs in the human endometrium. J Mol Endocrinol 5:103-108

15. Rebar RW 1989 The breast and the physiology of lactation. In: Creasy RK, Resnik R (eds) Maternal-Fetal Medicine. Principles and Practice. WB Saunders, Philadelphia, pp $153-170$

16. Hanamura T, Motoyoshi K, Yoshida K, Saito M, Miura Y, Kawashima T, Nishida M, Takaku F 1988 Quantitation and identification of human monocytic colonystimulating factor in human serum by enzyme-linked immunosorbent assay. Blood $72: 886-892$

17. Motoyoshi K, Suda T, Kusumoto K, Takaku F, Miura Y 1982 Granulocytcmacrophage colony stimulating and binding activities of purified human urinary colony-stimulating factor to murine and human bone marrow cells. Blood 60:13781386

18. Suzu S, Yanai N, Sato-Somoto Y, Yamada M, Kawashima T, Hanamura T, Nagata $\mathrm{N}$, Takaku F, Motovoshi K 1991 Characterization of macrophage colony-stimulating factor in body fluids by immunoblot analysis. Blood 77:2160-2165

19. Saito S, Motoyoshi K, Saito M, Kato Y, Enomoto M, Nishikawa K, Morii T, Ichijo M 1993 Localization and production of human macrophage colony-stimulating factor (hM-CSF) in human placental and decidual tissues. Lymphokine Cytokine Res $12: 101-107$

20. Soule HD, Vazquez S, Long A, Albert S, Brennan M 1973 A human cell line from a plcural cffusion derived from a breast carcinoma. J Natl Cancer Inst 51:1409-1415 
21. Engel LW, Young NA, Tralka TS, Lippman ME, O'Brien SJ, Joyce MJ 1978 Establishment and characterization of three new continuous cell lines derived from human breast carcinomas. Cancer Res 38:3352-3364

22. Yamane M, Nishiki M, Kataoka T, Kishi N, Amano K, Nakagawa K, Okumichi T, Naito M, Ito A, Ezaki H 1984 Establishment and characterization of new cell line (YMB-1) derived from human breast carcinoma. Hiroshima J Med Science 33:715720

23. Sekiguchi M, Johshi Y, Fujii G, Sudo K, Suzuki K 1979 Human breast cancer cell line of ascites form transplantable to nude mouse and the tissue culture cell line. Proceedings of the Japan Cancer Society Mecting 38:139

24. Lotem J, Sachs L 1979 Regulation of normal differentiation in mouse and human myeloid leukemia cells by phorbol esters and the mechanism of tumor promotion. Proc Natl Acad Sci USA 76:5158-5162

25. Howie P, Forsyth J, Ogston S, Clark A, Florey C du V 1990 Protective effect of breastfeeding against infection. BMJ 300:11-16

26. Skansén-Saphir U, Lindfors A, Andersson U 1993 Cytokine production in mononuclear cells of human milk studied at the single-cell level. Pediatr Res 34:213-216

27. Lippman M, Bolan G, Huff K 1976 The effects of estrogens and antiestrogens on hormone-responsive human breast cancer in long-term tissue culture. Cancer Res 36:4595-4601

28. Darbre P, Yates J, Curtis S, King RJB 1983 Effects of estradiol on human breast cancer cells in culture. Cancer Res 43:349-354
29. Soder O 1987 Isolation of interleukin-1 from human milk. Int Arch Allergy Appl Immunol 83:19-23

30. Munoz C, Endres S, Van Der Meer J, Schlesinger L, Arevalo M, Dinarello C 1990 Interleukin $1 \beta$ in human clostrum. Res Immunol 141:505-513

31. Saito S, Maruyama M, Kato Y, Moriyama I, Ichijo M 1991 Detection of IL-6 in human milk and its involvement in IgA production. J Reproduct Immunol 20:267276

32. Mushtaha AA, Schmalstieg FC, Hughes TK Jr, Rajaraman S, Rudloff HE, Goldman AS 1989 Chemokinetic agents for monocytes in human milk: possible role of tumor necrosis factor- $\alpha$. Pediatr Res 25:629-633

33. Rudloff HE, Schmalstieg FC, Mushtaha AA, Palkowetz KH, Liu SK, Goldman AS 1992 Tumor necrosis factor- $\alpha$ in human milk. Pediatr Res 31:29-33

34. Kauma S, Matt D, Strom S, Eierman D, Turner $T 1990$ Interleukin-1, human leukocyte antigen HLA-DR, and transforming growth factor $\beta$ expression in endometrium, placenta, and placental membranes. Am J Obstet Gynecol 163:1430-1437

35. Yelavarthi KK, Chen H-L, Yang Y, Cowley BD Jr, Fishback JL, Hunt JS 1991 Tumor necrosis factor- $\alpha$ mRNA and protein in rat uterine and placental cells. J Immunol $146: 3840-3848$

36. De M, Sanford TR, Wood GW 1992 Interleukin-1, interleukin-6, and tumor necrosis factor- $\alpha$ are produced in the mouse uterus during the estrous cycle and arc induced by estrogen and progesterone. Dev Biol 151:297-305 